\title{
Effect of Date of Transplanting on Growth and Productivity of Rice (Oryza sativa L.) Cultivars
}

\author{
Pardeep Kaur Mann, Balwinder Singh Dhillon
}

10.18805/ag.R-2158

\begin{abstract}
Background: In central Punjab, the primary cause of depleting underground water is early transplantation of long-duration rice varieties. Because of their growth in rainy days and early maturity, the cultivation of medium-duration varieties in the low evaporation period can help to migrate the over draft of underground water.

Methods: The field experiment entitled "Effect of date of transplanting on growth and productivity of the rice (Oriza sativa L.) cultivars" was conducted at Research Farm of University College of Agriculture, Guru Kashi University, Talwandi Sabo, Bathinda to study the impact of date of transplanting on growth and productivity of the rice cultivars during kharif season in 2019. The trail was laid out in split plot design with three dates of transplanting (June 15, June 25 and July 5) in main plot and three rice cultivars (PR 122, PR 126 and PUSA 44) in sub plot, replicated thrice.

Result: Transplanting on 15 June crop recorded significantly higher plant height at 30,60 DAT and at harvest viz. 67.4 , 110.0 and $122.6 \mathrm{~cm}$ respectively; number of tillers at 30,60 DAT and at harvest viz. 59.4, 58.2 and 46.2 respectively; leaf area index (LAI) at 60 DAT (3.1); dry matter accumulation (DMA) at 30, 60 DAT and at harvest viz. 8.5, 26.7 and 132.6 q/ha respectively; number of days taken to panicle initiation (57.6); number of days taken for 50 per cent flowering (64.1); effective tillers per meter row length (38.6); panicle length $(26.1 \mathrm{~cm})$; panicle weight $(6.1 \mathrm{~g})$; number of grains per panicle (177.9); 1000-grain weight (31.0g); grain yield (72.2 q/ha); straw yield (161.1 q/ha); harvest index (33.4\%). The grain yield was at par with June 25 . Among the cultivars, PUSA 44 recorded significantly higher plant height at 30,60 DAT and at harvest viz. 70.6, 117.4 and $128.6 \mathrm{~cm}$ respectively; number of tillers at 30, 60 DAT and at harvest viz. 65.0, 60.3 and 50.4 respectively; leaf area index (LAI) at 60 DAT (3.4); dry matter accumulation (DMA) at 30,60 DAT and at harvest viz. 9.5, 31.3 and $153.4 \mathrm{q} /$ ha respectively; number of days taken to panicle initiation (65.2); number of days taken for 50 per cent flowering (68.7); effective tillers per meter row length (43.2); panicle length (27.5 cm); panicle weight $(6.5 \mathrm{~g})$; number of grains per panicle (195.7); 1000-grain weight (34.7g); grain yield (80.1 q/ha); straw yield (181.2 q/ha); harvest index (34.1\%). June 15 transplanting produced significantly higher grain yield which was 1.5 and $6.4 \%$ higher than June 25 and July 5 transplanting respectively. PUSA 44 produced significantly higher grain yield which was 27.3 and $17.4 \%$ higher than PR 126 and PR 122 respectively. All the interaction effect of date of transplanting and rice cultivars recorded non-significant results.
\end{abstract}

Key words: Cultivars, Dates of transplanting, Grain yield, Rice.

\section{INTRODUCTION}

Rice (Oryza sativa L.) is the most important staple food crop of India. As rice generally accounts for 32 percent of the cropped region in Asia, the value of rice is more pronounced in Asia. In rice production, India is next to China. In India, rice is cultivated in an area of 44.6 million ha with a production of 109.5 million tons and an average productivity of 2.62 tons per ha. The slogan "Rice is Life" is best suited to India because this crop plays a vital role in our national food security and is a livelihood for millions of rural households. India's rice output goal for 2025 AD is expected to be 140 million tons, which can only be reached by growing rice production by 2 million tons per year over the current one in the next decade (Sridhar et al., 2011). Rice is grown in all regions of the world because of its large potential to cope with the changing agro-climates. Rice, which is India's main important food crop, provides about 45 per cent of total production and thus holds the secret to maintaining food sustainability in India (Rai and Kushwaha, 2008). It is the main crop in Kharif and ranks second in area, output and productivity in Punjab, after wheat.
Department of Agronomy, College of Agriculture, Guru Kashi University, Talwandi Sabo-151 302, Punjab, India.

Corresponding Author: Balwinder Singh Dhillon, Regional Research Station, Punjab Agricultural University, Ballowal Saunkhri-144 521, SBS Nagar, Punjab, India. Email: balwinderdhillon.pau@gmail.com How to cite this article: Mann, P.K. and Dhillon, B.S. (2021). Effect of Date of Transplanting on Growth and Productivity of Rice (Oryza sativa L.) Cultivars Agricultural Reviews. DOI: 10.18805/ag.R-2158. Submitted: 15-01-2021 Accepted: 07-07-2021 Online: 14-08-2021

Planting time is the major factor that determines the productivity of a crop. Optimum planting time for a crop is location specific. Optimum planting time worked out June 1-10 in Punjab (Gill et al., 2006). Early or delay in sowing leads to lower production of rice. Gravois and Helms (1996) also showed that rice grain yields declined as seeding date was delayed. At a specific location, maximum grain yield can be achieved by planting the crop at the optimum time, which may vary from variety to variety (Reddy and Narayana, 1984). Rice varieties exhibit wide variation in the production 
of high density grains which showed maximum potential for grain filling and test weight (Murty et al., 1992). Timely sowing of rice results in earlier harvest and allows timely planting of the next wheat or other crops. The rice- wheat system productivity was nearly 12 tons per ha when about 25 days old rice seedlings were transplanted before end of June. The total system productivity is reduced by more than 40 percent when field were planted after August 15 (Rai and Kushwaha, 2008). The specific sowing date for the rice transplanting also plays a crucial role in optimizing its growth and increasing the yield. The sowing time of the rice crop is important for three major reasons. Firstly, it ensures that vegetative growth occurs during a period of satisfactory temperatures and high levels of solar radiations. Secondly, the optimum sowing time for each cultivar ensures the cold sensitive stage occurs when the minimum night temperatures are historically the warmest. Thirdly, sowing on time guarantees that grain filling occurs when milder autumn temperatures are more likely, hence good grain quality is achieved (Farrell et al., 2003). Sowing date has a direct impact on the rate of establishment of rice seedling (Tashiro et al., 1999). Khalifa (2009) found that early sowing of rice recorded maximum tillering, panicle initiation, heading date, number of tillers/plant, plant height and root length at panicle initiation and heading stage, chlorophyll content, number of days to panicle initiation and heading date, leaf area index, sink capacity, spikelets/leaf area ratio, number of grains per panicle, panicle length $(\mathrm{cm}), 1000$-grain weight $(\mathrm{g})$, number of panicles $\mathrm{m}^{-2}$, panicle weight $(\mathrm{g})$ and grain yield (t/ha).

Scientists and policy-makers support delayed transplantation from a relatively higher to lower evaporative demand duration (May to late June). Likewise, rice being highly sensitive to diverse ecological conditions, adequate seedling age plays a crucial role in achieving potential yields; however, it behaves differently with the span of different cultivars. In addition, varieties differ in their seedling strength, competitiveness of the weeds, tolerance of submergence and drought, maturity, resistance lodging and productivity. In central Punjab, the primary cause of depleting underground water is early transplantation of long-duration rice varieties. Because of their growth in rainy days and early maturity, the cultivation of medium-duration varieties in the low evaporation period can help to migrate the over draft of underground water. This will certainly cause a serious problem for future sustainability. Therefore there is an immediate and urgent need to reduce the water consumption especially during the early establishment of the crop after transplanting. So there is a serious need to test the delaying of transplanting of the crop by at least 10-15 days late transplanting (from $15^{\text {th }}$ June to $25^{\text {th }}$ June), which is quite dry, hot and highly evaporating period. Rice, being a major kharif season crop of this area requires a study of growth and productivity and its association with different weather parameters. In view of above consideration the present investigation was planned to evaluate the effect of different transplanting dates on growth and productivity in different rice varieties.

\section{MATERIALS AND METHODS}

The present investigation entitled "Effect of date of transplanting on growth and productivity of rice (Oryza sativa L.) cultivars" was conducted at the experimental farm of the University College of Agriculture, Guru Kashi University, Talwandi Sabo, Bathinda. It is located between the latitude of $29.9875^{\circ} \mathrm{N}$ and the longitude of $75.0903^{\circ} \mathrm{E}$ with an altitude of 252 meters above mean sea level. The experimental site is part of a semi-arid climate in which both summers and winters are intense. During summer, a high temperature of around $45^{\circ}$ is not unusual, although freezing temperatures followed by frost may occur in the months of December and January. Normally, the monsoon season begins in the first week of July.

The soil was slightly alkaline $(\mathrm{pH} 7.9)$ with normal electrical conductivity $\left(0.24 \mathrm{dSm}^{-1}\right)$. The soil was medium in organic carbon content $(0.29 \%)$. The available nitrogen $\left(233.75 \mathrm{~kg} \mathrm{ha}^{-1}\right)$ was low, whereas the available phosphorus $\left(15.03 \mathrm{~kg} \mathrm{ha}^{-1}\right)$ and available potassium $\left(216.85 \mathrm{~kg} \mathrm{ha}^{-1}\right)$ were both medium. The experiment was laid out in split plot design with three replications.

The five plants were selected randomly from each plot, then height of these plants was measured at regular intervals in centimeters with a meter scale in each plot and it was estimated from ground level to the tip of the plant. From the two rows of plot, the total number of tillers per meter of row length was counted and the average was worked out. The leaf area index as calculated by multiplying the leaf length $x$ leaf width with correction factor $\mathrm{K} \times$ number of leaves per plant in each treatment. Plants were cut close to the ground to record dry matter accumulation of the different dates of observations; samples were oven dried at $70^{\circ} \mathrm{C} \pm 2^{\circ} \mathrm{C}$ till constant weight was achieved. Samples were weighed after drying to record the drying weight and expressed in $\mathrm{g}$. The panicle bearing tillers were recorded in the same way as number of tillers per meter row length were recorded during observation period. Five panicles were sampled from the tagged hills of each plot. The length was determined from the base of the panicle to the tip of the topmost spikelet. The mean panicle length was calculated and expressed in centimeters. The grains of five panicles selected for panicle length from each plot were counted carefully and averaged to obtain the number of grains per panicle. Five panicles were selected from marked area and were weighed and averaged to record weight per panicle. One thousand grains from the net plot of each treatment were counted and their weight recorded in gram and represented as the test weight. Produce of the net plots was threshed and grains thus obtained as winnowed, cleaned and weighed. The yield was recorded in $\mathrm{kg}$ per plot was standardized to 14 percent moisture and then weight was converted into q ha ${ }^{-1}$. Dry weight of straw collected from the net plot was recorded after sun drying for $4-5$ days and expressed in $q / h a$. The 
harvest index was calculated by dividing the economic yield by the biological yield and multiplying by 100 .

\section{RESULTS AND DISCUSSION Growth parameters of rice}

The data indicated that the rice planted on June 15 produced significantly taller plants as compared to the crop planted on June 25 and July 5 (Table 1). June 15 planting recorded 3.9 and $17.4 \mathrm{~cm}$ higher plant height than June 25 and July 5 planting, respectively. The late planting had shorter growing period due to photoperiod response and June planting was attributed favourable environmental conditions which enabled the plant to improve its growth and development as compared to July planting. These findings were in close agreement with those of Verma et al., (2004) and Choudhary et al., (2011). The tallest plants were recorded in PUSA 44 variety and it was significantly higher than $P R 126$ and $P R$ 122. PUSA 44 recorded 21.3 and $18 \mathrm{~cm}$ higher plant height than PR126 and PR122 rice cultivars respectively when observed. Rice planted on June 15 produced significantly higher number of tillers per meter row length as compared to the crop planted on June 25 and July 5 (Table 1). June 15 planting recorded 4.1 and 6 higher number of tillers per meter row length than June 25 and July 5 planting when observed respectively. The higher value of tillers might be due to availability of more time for growth period with optimum photoperiod as well as optimum temperature for the growth of crop plant which may result in more nutrient absorption by the roots for the synthesis of protoplasm responsible for rapid cell division which may increase the number of tillers. Similar results were also reported by Singh et al., (1996), Singh et al., (1997) and Mahajan et al., (2009). The maximum number of tillers was recorded under PUSA 44 and was significantly higher than PR 126 and PR 122. PUSA 44 recorded 13.7 and 9.1 higher number of tillers per meter row length than PR 126 and PR 122 rice cultivars, respectively. It is cleared from the data that rice planted on June 15 produced significantly higher leaf area index (LAI) as compared to the crop planted on June 25 and July 5
(Table 1). June 15 planting recorded 6.8 and 14.8 per cent higher LAI than June 25 and July 5 planting when observed.

The higher LAI might be due to more number of leaves and size which were accumulation of food material through photosynthesis during growth period of the crop and then distributed towards the root and shoot. The more LAI in early planting crop have also been reported by Samdhia (1996), Verma et al., (2004). The significantly higher LAI was recorded under PUSA 44 and was significantly higher than PR 126 and PR 122. PUSA 44 recorded 41.6 and 17.2 percent higher LAI than PR 126 and PR 122 rice cultivars when observed. The rice planted on June 15 produced significantly higher dry matter accumulation (DMA) as compared to the crop planted on June 25 and July 5 (Table 1). June 15 planting recorded 16.8 and 24.7 per cent higher DMA than June 25 and July 5 planting when observed respectively. The tallest plants and higher number of tillers might be due to the better development of early form tillers up to the stage of maximum tillering due to better photosynthesis activities of the plant in the optimum photoperiod at optimum temperature to supply energy in term of photosynthate for their proper development which may ultimately led to higher dry matter accumulation. Similar results were also reported by Patel et al., (1999). The maximum DMA was recorded under PUSA 44 and was significantly higher than PR 126 and PR 122. PUSA 44 recorded 86.3 and 31.44 per cent higher DMA than PR 126 and PR 122 rice cultivars respectively.

\section{Yield attributes of rice}

The rice planted on June 15 produced significantly higher number of effective tillers as compared to the crop planted on June 25 and July 5 (Table 2). June 15 planting recorded 3.2 and 5.0 higher number of effective tillers than June 25 and July 5 plantings, respectively at maturity. Late planting on July 5 might have exposed the crop to relatively more adverse environmental condition in terms of water stagnation during initially establishment and at tillering phase, low temperature at the reproductive phase which might have pulled down the number of effective tillers as compared to

Table1: Effect of different date of transplanting and rice cultivars on growth parameters of rice.

\begin{tabular}{lcccc}
\hline Treatments & $\begin{array}{c}\text { Plant height } \\
(\mathrm{cm})\end{array}$ & $\begin{array}{c}\text { Number of tillers per } \\
\text { meter row length }\end{array}$ & $\begin{array}{c}\text { Leaf area } \\
\text { index (\%) }\end{array}$ & $\begin{array}{c}\text { Dry matter } \\
\text { accumulation }(\mathrm{q} / \mathrm{ha})\end{array}$ \\
\hline Dates of transplanting & 122.6 & 46.2 & 3.1 & 132.6 \\
June 15 & 118.7 & 42.1 & 2.9 & 113.5 \\
June 25 & 105.2 & 40.2 & 2.7 & 106.3 \\
July 5 & 1.3 & 0.7 & 0.08 & 8.7 \\
LSD (P=0.05) & & & & 116.7 \\
Cultivars & 110.6 & 41.3 & 2.9 & 82.3 \\
PR 122 & 107.3 & 36.7 & 2.4 & 153.4 \\
PR 126 & 128.6 & 50.4 & 3.4 & 8.3 \\
PUSA 44 & 0.7 & 1.0 & 0.06 & $\mathrm{NS}$ \\
LSD (P=0.05) & $\mathrm{NS}$ & $\mathrm{NS}$ & $\mathrm{NS}$ \\
Interaction & & & \\
\hline
\end{tabular}


Effect of Date of Transplanting on Growth and Productivity of Rice (Oryza sativa L.) Cultivars

Table 2: Effect of different date of transplanting and rice cultivars on yield attributes of rice.

\begin{tabular}{|c|c|c|c|c|c|c|c|}
\hline Treatments & $\begin{array}{c}\text { Effective tillers } \\
\text { per } m \text { row length }\end{array}$ & $\begin{array}{c}\text { Panicle } \\
\text { length }(\mathrm{cm})\end{array}$ & $\begin{array}{c}\text { Panicle } \\
\text { weight }(\mathrm{g})\end{array}$ & $\begin{array}{c}\text { No. of grains } \\
\text { per panicle }\end{array}$ & $\begin{array}{c}\text { 1000-grain } \\
\text { weight }\end{array}$ & $\begin{array}{l}\text { Grain yield } \\
\text { (q/ha) }\end{array}$ & $\begin{array}{c}\text { Straw } \\
\text { yield }(q / h a\end{array}$ \\
\hline \multicolumn{8}{|c|}{ Dates of transplanting } \\
\hline June 15 & 38.6 & 26.1 & 6.1 & 177.9 & 31.0 & 72.2 & 161.1 \\
\hline June 25 & 35.4 & 25.6 & 5.7 & 173.7 & 29.6 & 71.1 & 150.5 \\
\hline July 5 & 33.6 & 24.9 & 5.3 & 163.5 & 28.2 & 67.8 & 139.0 \\
\hline LSD $(P=0.05)$ & 1.4 & 0.3 & 0.3 & 5.8 & 1.1 & 2.1 & 6.5 \\
\hline \multicolumn{8}{|l|}{ Cultivars } \\
\hline PR 122 & 34 & 25.5 & 5.6 & 168.7 & 28.8 & 68.2 & 147.1 \\
\hline PR 126 & 30.5 & 23.6 & 5.0 & 150.7 & 25.3 & 62.9 & 122.4 \\
\hline PUSA 44 & 43.2 & 27.5 & 6.5 & 195.7 & 34.7 & 80.1 & 181.2 \\
\hline LSD $(P=0.05)$ & 1.1 & 0.7 & 0.2 & 8.0 & 1.4 & 1.0 & 6.6 \\
\hline Interaction & NS & NS & NS & NS & NS & NS & NS \\
\hline
\end{tabular}

earlier planting on June 15. The results are also confirmed the findings of Gangwar and Ahmadi, (1990) and Akbar et al., (2010). The maximum number of effective tillers was recorded under PUSA 44 and was significantly higher than PR 126 and PR 122. PUSA 44 recorded 12.7 and 9.2 higher number of effective tillers than PR 126 and PR 122 rice cultivars when observed at maturity respectively. The rice planted on June 15 had significantly higher panicle length as compared to the crop planted on June 25 and July 5 (Table 2). The maximum panicle length was recorded under PUSA 44 and was significantly higher than PR 126 and PR 122. Such variation in panicle length may be directly related with the growth parameters of varieties. Better in plant growth better would be the photosynthetic process there by increased accumulation of photosynthates for their translocation towards reproductive organs. The significant difference in yield attributes among the rice varieties have also been reported by Mukesh et al., (2009). The transplanting of rice on June 15 significantly increased the weight of the panicle. Delay in transplanting on June 25 and July 5 caused (Table 2) significant reduction in weight panicle $^{-1}$ as compared to June 15 which might be due to availability of longer period for better development of plant parts to allocate greater accumulation of photosynthates in early planted crop which may result in the better development of yield attribute characters viz. panicle weight. Similar results were also reported by Chaudhary et al., (2011). The maximum panicle weight was recorded under PUSA 44 and was significantly higher than PR 126 and PR 122. The rice planted on June 15 had significantly higher number of grains per panicle as compared to the crop planted on June 25 and July 5 (Table 2). However, it was statistically at par with June 25 . The maximum number of grains per panicle was recorded under PUSA 44 and was significantly higher than PR 126 and PR 122. It might be due to the better photosynthetic process which results in increased accumulation of photosynthates for their translocation towards reproductive organs. Similar results were also reported by Nayak et al., (2003), Suresh et al
(2013). The rice planted on June 15 had significantly higher 1000 -grain weight as compared to the crop planted on June 25 and July 5 (Table 2). The reduction in delayed transplanting 1000-grain weight might be due to the weather condition as delayed transplanting seedling could be unable to get longer period for better development of plant parts which may result in better development of yield attributing characters such as 1000-grain weight. Similar results were also reported by Paliwal et al (1996), Singh et al (2004). The maximum number of grains per panicle was recorded under PUSA 44 and was significantly higher than PR 126 and PR 122. The different transplanting dates brought about significant impact upon the production of grains (Table 2). Accordingly, out of different transplanting dates, earliest June 15 planting performed best in grain production. Thus June 15 planting produced significantly 1.5 and 6.4 per cent higher grain yield than June 25 and July 5 respectively. But it was at par with June 25 transplanting. The higher grain yield in early planted crop might be due to optimum period available for growth and development resulting in more storage of photosynthates in grain observed under earlier planted crop than the later planted crop. These findings are confirmed by Kabat and Satapathy, (2013). There is significant impact of different rice cultivars upon the production of rice grains. Amongst the cultivars, PUSA 44 took a lead producing significantly 27.3 and 17.4 per cent higher grain yield than PR 126 and PR 122, respectively. The rice transplanted on June 15 significantly increased the straw yield (Table 2). Delay in transplanting on June 25 and July 5 caused significant reduction as compared to June 15. Thus June 15 planting produced significantly 7.04 and 15.8 per cent higher grain yield than June 25 and July 5 , respectively. There is significant impact of different rice cultivars upon the production of rice straw yield. Amongst the cultivars, PUSA 44 took a lead producing significantly 48.0 and 23.1 per cent higher straw yield than PR 126 and PR 122 respectively. Due to marked improvement in growth and yield attributes proved instrumental in increasing straw yield under earlier planted crop. Similar results were also reported by Verma et al., (2004) and Pandey et al., (2008). 


\section{CONCLUSION}

Among the dates of transplanting of rice, June 15 proved as the optimum date of transplanting which gives maximum growth parameters and yield attributes. Among the rice cultivars, PUSA 44 resulted as the better rice cultivar which gives maximum growth parameters and yield attributes.

\section{REFERENCES}

Akbar, N., Iqbal, A., Khan, H.Z., Hanif, M.K. and Bashir, M.U. (2010) Effect of sowing dates on the yield and yield components of direct seeded fine rice (Oryza sativa L.). Journal of Plant Breeding and Crop Science. 2(10): 312-315.

Chaudhary, S.K., Singh, J.P. and Jha, S. (2011). Effect of integrated nitrogen management on yield, quality and nutrient uptake of rice under different dates of planting. Indian Journal of Agronomy. 56(3): 228-231.

Farrell, T.C., Fox, K., Williams, R.L., Fukai, S. and Lewin, L.G. (2003) Genotypic variation for cold tolerance during reproductive development in rice (Oryza sativa L.): Screening with cold air and cold water. Field Crops Research. 96(2-3): 178-194.

Gangawar, B. and Ahamedi, R. (1990). Effect of planting time on growth, yield and incidence of insect pests in rice, Oryza. 27: 497-500.

Gill, M.S., Kumar, A. and Kumar, P. (2006). Growth and yield of rice (Oryza sativa L.) cultivars under various methods and times of sowing. Indian Journal of Agronomy. 51(2): 123-127.

Gravois, K.A. and Helms, R.S. (1996). Seeding rate effect on rough yield, head rice and total milled rice. Agronomy Journal. 88: 82-84.

Kabat, B. and Satapathy, M.R. (2013). Effect of planting dates and $\mathrm{N}$ levels on grain yield and $\mathrm{N}$ uptake by hybrid rice. OryzaAn International Journal on Rice. 50(4):409-411.

Mahajan, G., Bharaj, T.S. and Timsina, J. (2009). Yield and water productivity of rice as affected by time of transplanting in Punjab, India. Agriculture Water Management. 96: 525-532.

Mukesh, S.I., Pannu, R.K., Prasad, D. and Ram, A. (2009). Effects of different transplanting dates on yield and quality of basmati rice varieties. Indian Journal of Agronomy. 58: 256-258.

Murty, P.S.S., Ramesh, K.S., Rao, G.V.H. and Naryayanan. (1992) Influence of Nitrogen on grain filling potential and yield of rice (Oryza sativa L.) varieties. Indian Journal of Agronomy. 37: 157-158.

Nayak, B.C., Dalei, B.B. and Chodhury, B.K. (2003). Response of hybrid rice to date of planting, spacing and seedling rate during wet season. Indian Journal of Agronomy. 48(3): 172-174.

Khalifa, A.A.B.A. (2009). Physiological evaluation of some hybrid rice varieties under different sowing dates. Australian Journal of Chemistry. 15(2): 78-183.
Paliwal, A.K., Khandalker, V.S., Paraye, P.M. and Tomar, N.S. (1996) Effect of transplanting time on grain yield and its attributes in dwarf scented rice. Indian Journal of Agricultural Sciences. 66(1): 48-50.

Pandey, N., Verma, A.K. and Tripathi, R.S. (2008). Effect of planting dates and $\mathrm{N}$ levels on $\mathrm{N}$ concentration in the leaf, grain yield and $\mathrm{N}$ uptake by hybrid rice. Oryza- An International Journal on Rice. 45(1): 18-22.

Patel, J.R. (1999) Response of rice to time of transplanting, spacing and age of seedlings. Indian Journal of Agronomy. 44(2): 344-346.

Rai, H.K. and Kushwaha, H.S. (2008). Effect of planting dates and soil water regimes on growth and yield of upland rice. Oryza- An International Journal of Rice. 45(2): 129-132.

Reddy, S.N. and Narayana, P. (1984). Pattern of dry matter accumulation and $\mathrm{N}$ uptake by rice as influenced by age of seedling and date of planting. Andhra Agriculture Journal. 32: 15556.

Samdhia, S. (1996). Relative performance of hybrids rice under different dates and densities of planting. IRRN. 81-82.

Singh, CB., Aujla, T.S., Sandhu, B.S. and Khehra, K.L. (1996). Effect of transplanting date and irrigation regime on growth, yield and water use efficiency in rice in northern India, Indian Journal of Agricultural Sciences. 33(3): 137141.

Singh, K.M., Pal, S.K., Verma, U.N., Thakur, R. and Singh, M.K. (1997). Effect of time and methods of planting on performance of rice cultivars under medium land of Bihar plateau. Indian Journal of Agronomy. 42(3): 443-445.

Singh, M.V., Tripathi, H.N. and Tripathi, H.P. (1997). Effect of nitrogen and planting date on yield and quality of scented rice. Indian Journal of Agronomy. 42(4): 602-606.

Singh, T., Shivay, Y.S. and Singh, S. (2004). Effect of date and transplanting and nitrogen on productivity and nitrogen use induces in hybrid and non-hybrid aromatic rice. Acta Agronomica Hungarica. 52(3): 245-252.

Sridhar, C.J., Ramchandappa, B.K., Nanjappa, H.V. and Mavarkar, N.S. (2011) Effect of genotypes, planting geometry and method of establishment on growth and yield of aerobic rice. Mysore Journal of Agriculture Science. 45(3): 501-505.

Suresh, B.G., Sravan, T. and Reddy, A. (2013). Interrelationship and cause-effect analysis of rice genotype in North-East plain zone. An International Quarterly Journal of Life Sciences. 8(4): 1141-1144.

Tashiro, T., Saigusa, M. and Shibuya, K. (1999) A trial of no-tillage direct seeding of rice (Oryza sativa L.) at early spring in cold climate region in Japan. Japanese Journal of Crop Science. 68(1): 146-150.

Verma, A.K., Pandey, N. and Tripathi, R.S. (2004) Leaf growth, chlorophyll, nitrogen content and grain yield of hybrid rice as influenced by planting times and nitrogen levels. Annals of Agricultural Research. 25(3): 456-458. 